\title{
Research and development of modern universities' essence
}

\author{
Sergey A. Prokopenko ${ }^{1}$, Tatiana S. Selevich ${ }^{1 a}$ \\ ${ }^{1}$ Tomsk polytechnic university, 634050 Lenin str., 30, Tomsk, Russia
}

\begin{abstract}
The authors have investigated the nature of the university and its manifestations. It is possible to reveal the basis of the current low competitiveness of Russian universities. The authors consider that university essence is a combination of three factors - spirit, intelligence and energy of the staff. Approaches to determine the levels of essence are shown in the article. This structure exists in the system "labor management - capital - technology". This construct forms the system of functioning of the modern university. The difference between the Russian and foreign universities lies in the development degree of the three basic components. A high development degree manifests the true essence of the university - to be a space of high concentration of advanced intellect, saturated with the spirit and energy of the cognition and transformation of new ideas into the effects of society.
\end{abstract}

\section{Introduction}

Low competitiveness of Russian universities on global research and education market explains the fact that only 21 national universities (from 1100) are included in the world ranking "QSWorldUniversityRanking". Its hold the 108th position (Moscow State University) up to $701 \mathrm{st}+$ (Voronezh state University) as for the end of 2015 [1]. Only 9 Russian universities entered the TOP 500. The reasons for this situation are numerous, they are widely analyzed and described in detail in the Russian scientific literature [2-5].

The competitiveness of the University depends on many factors, conditions and states. A breakthrough, a significant increase in the level of competitiveness requires essential renewals.

The essence as a philosophical category, is the opposite of the phenomenon. If the phenomenon is perceived by the human senses, the essence, the inner content of the object is revealed only to the mind. To see the large number of universities, different in size, range of faculties and institutes, specialization, function, lifetime, etc. in common, what underlies each of them - the essence - is of a great theoretical and practical value. It allows to move from superficial improvements to a justified radical renewal of this important organization.

\section{Materials and methods}

Authors used analytical and dialectical methods of cognition of reality to identify the contradictions between the essence of the University and its manifestation in the institutions of higher education in the XXI century. Authors studied classical and contemporary points of view on university education, on its nature and historical changes since the advent of the first universities to date. Authors studied the mission of Russian and foreign universities-leaders in the education market.

Based on the research of activity of Siberian universities, in particular those in Kuzbass, a number of Tomsk and Krasnoyarsk universities, authors held their essential analysis.

\section{Results and discussion}

The essence of the University, its purpose is usually expressed in the form of the mission. "The main mission of the University is the development of intellect and spirituality, which are considered as the ultimate goals of University education," wrote George. G. Newman [6].

We have to understand that the mission is the expression of the desired condition and position of the University in society, its super goal. The real state of the universities differs significantly from the mission ones and even more from the essential ones. The degree of manifestation of an essence in a particular university is different, determining the difference of their competitiveness and the possibility of being placed in the field of world education market (Fig. 1).

\footnotetext{
a Corresponding author: popova_ts@rambler.ru
} 


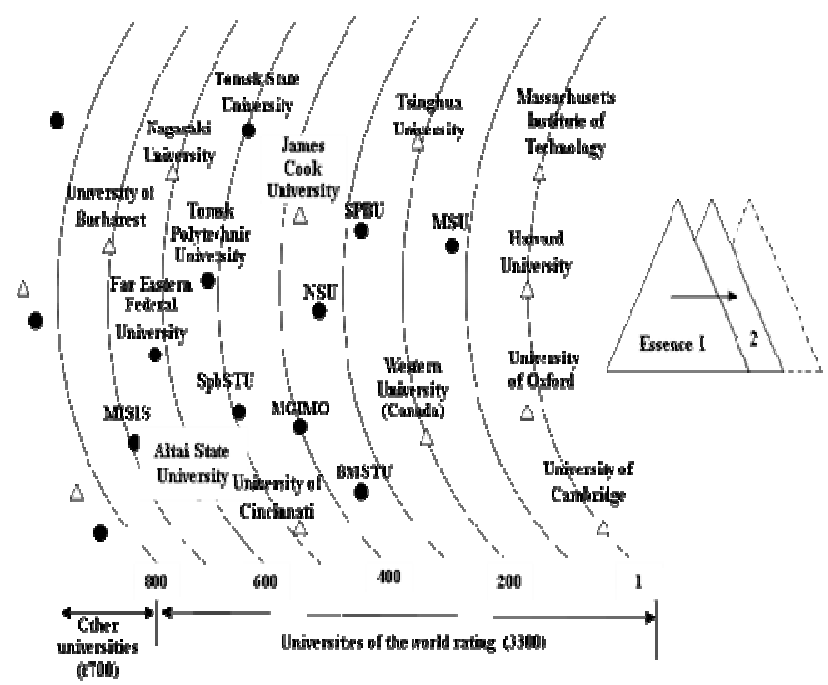

Fig. 1. The essence of the University and its current manifestations

The essence, the inner content of the University is stable, but not frozen philosophical category. Historical perspective allows us to highlight the pioneering essence (1) of the university (since their appearance on Earth in the 11th century until the 20th century) and contemporary essence (2) of the University [7].

The essence 1 of the university for nine centuries was in universality of the provided knowledge, the development of freethinking and citizenship, the formation of the cultural worldview, spiritual and moral perfection of a person, his socialization. Spokesmen for the university essence of the time are prominent thinkers, such as J. Newman, J. G. Fichte, A V. Humboldt, I. Kamensky, K. Jaspers $[6,8]$. This essence can be described as humanitarian, spiritual.

As a reflection of social changes brought by the industrial revolution, fragmentation and deepening of science, strengthening of the role of natural and technical Sciences, their professionalization and rationalization in place of the old contents of the university in the twentieth century came the pragmatic essence 2 . This essence of the university is in a deep specialization of knowledge, its commercialization, the growing pragmatism of the corporate culture of "high quality", the preparation of competent graduates, bureaucratization of the educational process [9-13].

The structure and levels of manifestation of the essence of the University

Analysis, synthesis and understanding of the mission and the entities of universities allow us to know that the essence as seen by A. Schopenhauer, is will of the organization called "university" is to desire to know reality and to update the ideas of mankind. The strength of this commitment is determined by the unity of three components: spirit, intelligence, energy.

Understanding the nature of the University allowed to develop the following definition: from the essence point of view, the University is a space of high concentration of advanced intellect, saturated with the spirit and energy of the cognition and transformation of new ideas into the effects of society. The spirit, in application to the essence of the University, refers to the internal strength, attitude, focus of staff on free cognition and creativity, so that there is aspiration, conviction and selfconfidence. The intelligence is understood as a general ability of sense perception, thinking, imagination of new concepts and ideas. Energy acts as activity, activity in understanding the reality of the new generation, the implementation of the results with the pace and effect need by the society.

In its turn, the will of the university determines the state of its key structural element - labor. In the scientific papers of STC-SRI the structure of the organization consisting of elements is shown as: labor, capital, technology, management. The manifestation of the will in the structure of the university is shown in Fig. 2.

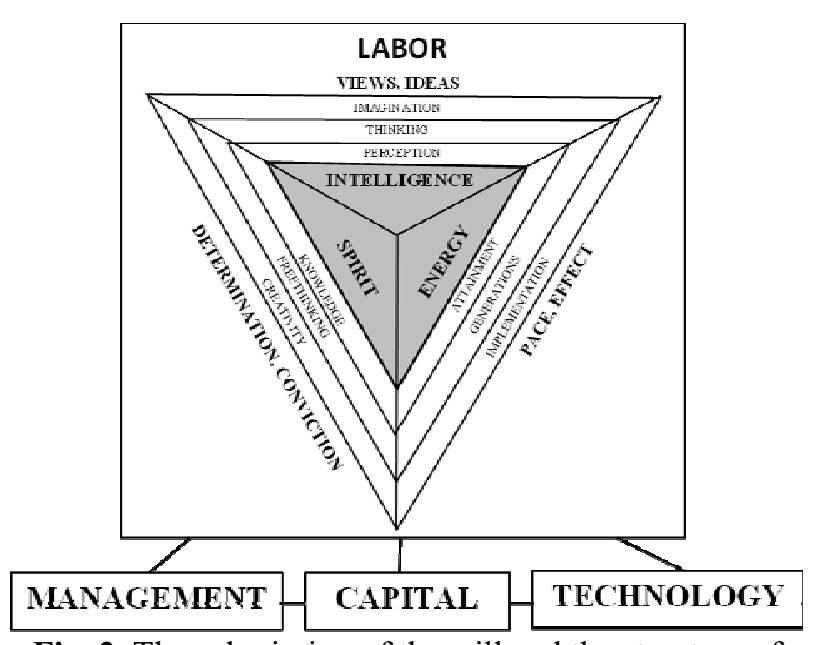

Fig. 2. The submission of the will and the structure of the university

The labor is the meaning of human existence and its organizations. University labor, as an appropriate cognitive and transformative activity, is determined by the spirit, intellect and energy of people, gathered under the roof of university. This activity is aimed at increasing the academic (and human) capital, it is managed and executed on special technology.

Depending on the quality, quantity, relations and connections of the structural elements and components of an essence, it acquires different and multiple (in the world, with over 10,000 universities) manifestations in specific universities, their functions and states. The condition of phenomena determines the degree of its proximity, the compliance essence. To characterize the extent to which the university as a phenomenon the following levels are proposed: essential, distant and visible (fig. 3).

The level of the "essence" of the university is an unattainable ideal, an absolute, eternal purpose. The concrete manifestation of the university in the first approximation can evaluate the quality of essence members: high, medium, low. Level "essence" corresponds to the university, having all the components at a high level. The level of the "similar" is a characteristic of the university with the average quality of the structural components of an essence. With low spirit, intelligence and energy of the University, it is in fact, "distant" from the true (ideal) level. Other 
combinations of structural elements of the essence define the intermediate levels from the provisions of the phenomenon of "university".

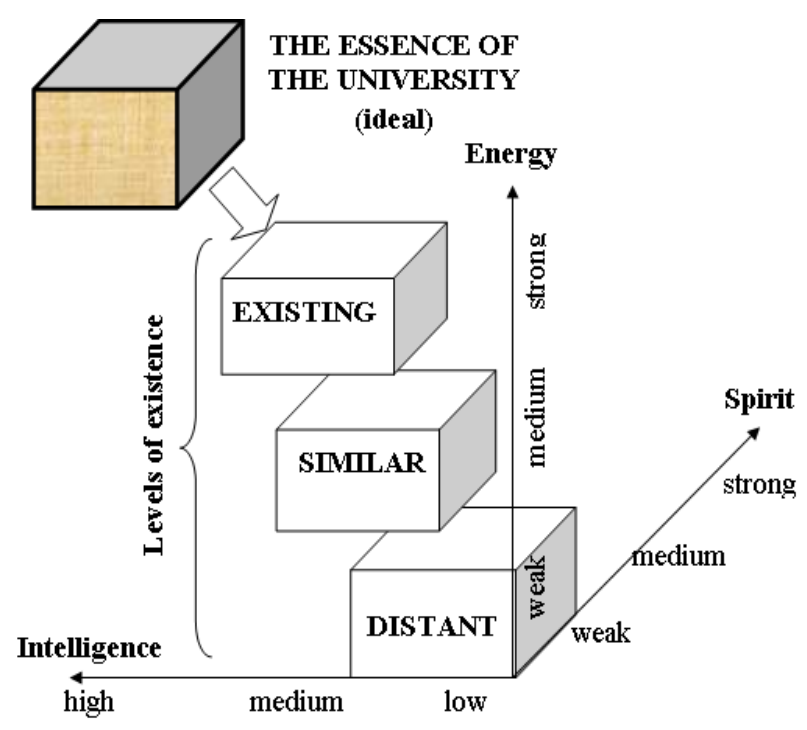

Fig. 3. The levels of university essence manifestation

According to the latest information some Russian universities and are manifested at the level below the lower. This level of visibility, a false essence, when the spirit, intelligence or energy are stressed, are in confused state or missing entirely. Such universities exist as an office for the sale of diplomas of higher education.

The dialectical development of a specific university requires its diagnosis as a phenomenon and development of a strategy for the change through successive state transitions from the current existence to the essential. The attainment of the same essence, in turn, allows us to move its content to a phenomenon, refining and developing it. The advanced universities in the world can serve as models for the desired attainment of the essence for Russian universities.

Essential analysis of Siberian universities, in particular those of Kuzbass, a number of Tomsk and Krasnoyarsk ones, etc. shows that in these organizations, in reality, the continued low level of spirit, intellect, and energy of the knowledge that does not meet the conditions of sustainable existence and development in the highly competitive global educational market.

Characteristic of these universities are state of uncertainty and impending doom of staff, management confusion, lost expectations of students. It is most effective to start the increase of competitiveness, availability of resources, viability of the organization with the essential renewal of the university.

\section{The essence of the elements of the University.}

With the aim of improving the competitiveness of the university on the basis of the essential renewal of its system components they developed definitions of their entities according to the levels of organization (table 1).
Table 1. The existence of entities of the University

in Russian education in XXI century

\begin{tabular}{|c|c|c|}
\hline \multirow{2}{*}{$\begin{array}{c}\text { Objec } \\
\mathrm{t}\end{array}$} & \multicolumn{2}{|c|}{ A brief expression of dialectical opposites } \\
\hline & essences & phenomena \\
\hline 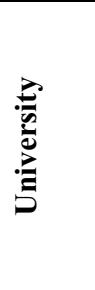 & $\begin{array}{l}\text { Space of high } \\
\text { concentration of intellect, } \\
\text { saturated with the spirit } \\
\text { and energy of the } \\
\text { cognition } \\
\text { transformation of new } \\
\text { ideas into the effects of } \\
\text { society }\end{array}$ & $\begin{array}{l}\text { Higher educational- } \\
\text { scientific institution, } \\
\text { which trains specialists } \\
\text { in many fundamental } \\
\text { and applied sciences, } \\
\text { various branches of } \\
\text { national economy and } \\
\text { culture }\end{array}$ \\
\hline \multicolumn{3}{|c|}{ System elements } \\
\hline 遇 & $\begin{array}{l}\text { Body for joint research of } \\
\text { the strategic decisions and } \\
\text { their approval }\end{array}$ & $\begin{array}{l}\text { An instrument to } \\
\text { legalize the positions } \\
\text { and decisions of the } \\
\text { rectorate }\end{array}$ \\
\hline 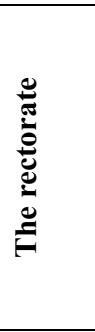 & $\begin{array}{l}\text { Spiritual, ideological } \\
\text { target catalyst of the } \\
\text { university renewal. } \\
\text { Developer and guide of } \\
\text { the strategy. The resource } \\
\text { allocator for systems of } \\
\text { the university }\end{array}$ & $\begin{array}{l}\text { The doer of orders of } \\
\text { the Ministry of } \\
\text { education. The great } \\
\text { body of tactical and } \\
\text { operational } \\
\text { management. The hub } \\
\text { and allocator of } \\
\text { resources at all levels of } \\
\text { the university }\end{array}$ \\
\hline 莺 & $\begin{array}{l}\text { Organizer of the cognitive } \\
\text { process on its scientific } \\
\text { direction }\end{array}$ & $\begin{array}{l}\text { The organizer of } \\
\text { financial and economic } \\
\text { activity of the team }\end{array}$ \\
\hline 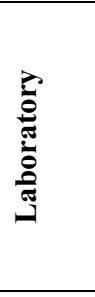 & $\begin{array}{l}\text { Structure of scientific } \\
\text { knowledge unknown to } \\
\text { humanity in a dedicated } \\
\text { sector of reality. Media of } \\
\text { cognitive spirit and } \\
\text { energy to renew views } \\
\text { and preliminary proposals } \\
\text { for the society }\end{array}$ & $\begin{array}{l}\text { Staff completed and } \\
\text { equipped team of } \\
\text { scientists, organized to } \\
\text { solve crucial scientific } \\
\text { objectives on a } \\
\text { particular subject }\end{array}$ \\
\hline 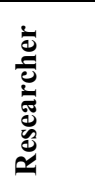 & $\begin{array}{l}\text { Passionate researcher of } \\
\text { reality and methods of its } \\
\text { transformation }\end{array}$ & $\begin{array}{l}\text { The researcher of } \\
\text { assigned problems and } \\
\text { the developer of } \\
\text { scientific solutions }\end{array}$ \\
\hline 氖 & $\begin{array}{l}\text { The complementary } \\
\text { community of scientists, } \\
\text { transforming research } \\
\text { achievements in advanced } \\
\text { training courses, manuals, } \\
\text { lectures and seminars. } \\
\text { Media of educational } \\
\text { culture of the institute }\end{array}$ & $\begin{array}{l}\text { Staffing group of } \\
\text { teachers of different } \\
\text { specializations and } \\
\text { qualifications, churning } \\
\text { out graduates with } \\
\text { diplomas. Place of } \\
\text { employment of teachers }\end{array}$ \\
\hline 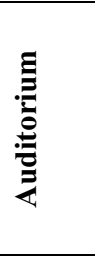 & $\begin{array}{l}\text { Space designed for the } \\
\text { effective transformation } \\
\text { of knowledge of one into } \\
\text { intellectual increment of } \\
\text { many and inspire them to } \\
\text { self-research of the } \\
\text { studied subject }\end{array}$ & $\begin{array}{l}\text { The space equipped } \\
\text { with multimedia } \\
\text { facilities and equipment } \\
\text { for lectures and } \\
\text { seminars }\end{array}$ \\
\hline
\end{tabular}




\begin{tabular}{|c|c|c|}
\hline 巳ัঠ & $\begin{array}{l}\text { The one to explain } \\
\text { complex phenomena of } \\
\text { reality and cognition, } \\
\text { teaching other with } \\
\text { interest }\end{array}$ & $\begin{array}{l}\text { Lecturer and presenter } \\
\text { of seminars with } \\
\text { students. The examiner }\end{array}$ \\
\hline 节 & $\begin{array}{l}\text { Focused on the } \\
\text { development of the depth } \\
\text { of knowledge and } \\
\text { originality of the thinking, } \\
\text { mastering scientific way } \\
\text { of thinking, mastering the } \\
\text { skills of solving typical } \\
\text { problems in the specialty }\end{array}$ & $\begin{array}{l}\text { Aspiring for a diploma } \\
\text { of higher education }\end{array}$ \\
\hline
\end{tabular}

Proposed characteristics of the essence elements allow the university to identify the distance from current events. A significant deviation of phenomena from entities is the main obstacle for improving the quality and competitiveness of the university. The quality of the university is integrated and is determined by how consistent with the essence of its current state are all organizational levels. Program development (sequencing and timing) of increasing the competitiveness of the university requires the prior development of methods for approximation of the phenomenon to the essence of each element of the system on the basis of targeted development of the structural components of essence: spirit, intelligence, energy.

Will (the essence) of the university lies in the pursuit of learning and renewing representations of mankind (Fig. 4).

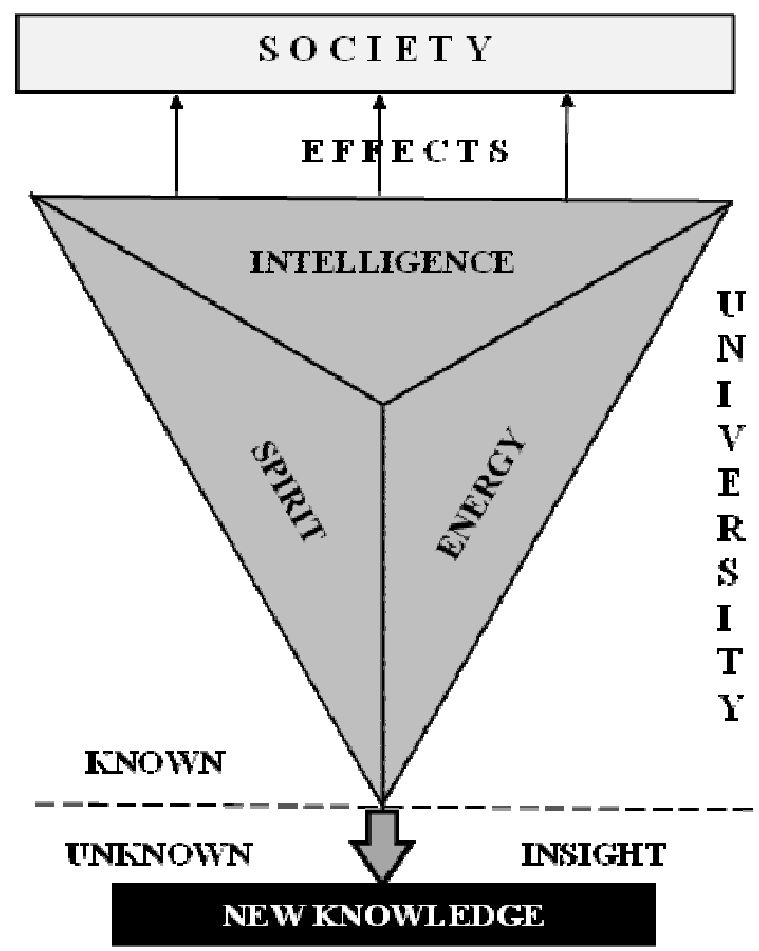

Fig. 4. Idea model of the university

The idea of the University is that a learning spirit, an advanced intellect and an active creative energy of people are concentrated on the brink of the "knownunknown". Directional penetration into the unknown allows us to go beyond the limits of known knowledge, to understand the still unknown, and then the learned things and to turn them into new ideas, discoveries, breakthrough developments. The university is designed to update the society with scale effects. This is its uniqueness compared to other scientific and educational institutions of people. It is this exceptionalism, this idea that determines the organizational structure of the university, its technology activities, personnel requirements, necessary capital, the specifics of management, etc.

This desire is in the structure of "spirit-intelligenceenergy", which resides in the structure of "labormanagement-capital-technology", which, in turn, forms a system of scientific, educational, managerial, financial, personnel, economic... Being in the will and desire in a depressed state is characterized by the current state of many Russian universities. Essential (efficient) renewing and improving the competitiveness of the university requires immediate change of spirit, intellect, and energy of workers.

\section{Conclusion}

The investigation into the nature of the university and its manifestations allowed to reveal the basis of the current low competitiveness of Russian universities. It is established that the structure essence of the University creates a unity of spirit, intellect, and energy of staff that Russian universities differ substantially from those existing in the leading universities of the world market of education. From the essential point of view, the university is a space of high concentration of advanced intellect, saturated with the spirit and energy of the cognition and transformation of new ideas into the effects of society.

According to the degree of alienation from the essence, the universities are found to beat levels of manifestations: essential, similar, distant and visible. The level of existence of the university is an integral expression of the phenomena of nature of all its system elements across hierarchical levels. Formulated entities of the system elements of the Russian university of the early twenty-first century allow us to understand a high degree of remoteness of their current manifestations. The established differences in the dialectical opposites of "essence-phenomenon" enable meaningful approach to developing effective methodological basis for improving the competitiveness of the university.

\section{References}

1. QS Top University Rankings (2015) [Online], [Retrieved March 18, 2016], http://www.topuniversities.com/university-rankings

2. E.A. Kobets, M.A. Masych, Mediterranean Journal of Social Sciences, 6, 354 (2015)

3. T.S. Selevich, O.S. Selevich, V.V. Golubeva, Procedia - Social and Behavioral Sciences, 174, (2015)

4. I.A. Gurban, A.B. Sudakova, Mediterranean Journal of Social Sciences, 6, 551 (2015) 
5. S.A. Prokopenko Journal University Management: Practice and Analysis, 5 (51), (2007)

6. J.G. Newman, University' idea (Minsk, 2006)

7. S.A. Prokopenko, T.S. Selevich, Philosophy of Education, 6, 63 (2015)

8. K. Jaspers, Electronic Library of $B G U$.

9. R. Barnet, Journal of Higher School, 6, (2008)

10. J. Ortega-i-Gasset, Fatherland' notes, 2, (2002)

11. A. Sogomonov, Fatherland' notes, 2, (2002)

12. E.N. Ivanhnenko, Higher Education in Russia, 2, (2013)

13. S.A. Prokopenko, Journal University Management: Practice and Analysis, 2, (2011) 